\title{
Payment of Final Income Tax Before the Issuance of Deed of Sale and Purchase in Legal Certainty Perspective
}

\author{
I Nyoman Putu Budiartha, I Nyoman Alit Puspadma \\ Faculty of Law \\ Universitas Warmadewa \\ Denpasar-Bali, Indonesia \\ budiarthaputu59@gmail.com
}

\begin{abstract}
The objective of this study is to examine the obligation to pay the Final Income Tax by the seller of land and/or building rights before the sale and purchase certificate is signed in the presence of the Land Deed Official (PPAT) as regulated in Article 3 paragraph (1) and (5) of Act 34 Year 2016. Research method used is descriptive method under a sociolegal approach. Data were obtained from document studies and field research through interviews with several informants. Data were analyzed using legal certainty theory and authority theory. Based on the results of data analysis, it is obtained that the obligation to pay the final income tax before the deed is signed in the presence of PPAT, can result in the absence of legal certainty guarantee, so that it potentially causes harm to society and disrupts the balance of community life order.
\end{abstract}

Keywords - income tax; authentic deed; sale and purchase of land rights; PPAT

\section{INTRODUCTION}

In order to create an orderly society, justice created through the institutions that maintain and regulate justice is intensely required. Legal studies, according to Roscoe Pound, explores about the implementation of justice, which means regulating the relationships and controlling the behavior of human beings into norms or legal principles are created [1].

According to Sudikno Mertokusumo, the law serves to protect the interests of people or society, while the goal is to discipline society. If human interests are protected, society will be orderly. The law is responsible for establishing a balance of order and legal certainty within society to realize its objective, namely to create a public order [2]. In order to fulfill the public obligation to pay income tax from the transfer of land and/or building rights to the state, promising regulations, namely Government Regulation Number 34 Year 2016 concerning Income Tax, especially income from Land Transfer and/or Building and Sale and Sale Agreement Land and/or Building and its amendments (hereinafter referred to as Law 34 Year 2016) are stipulated. Similarly, to meet the community's need for legal certainty, the legal arrangements concerning the transfer of rights to land and/or buildings, and the provisions of the competent authority to issue the land deed, namely the Land Deed Official (PPAT) as the official authors of authentic deeds has been established, so that every land title transactions, including through sales and purchase channels, is evidenced by the PPAT deed.

After the enactment of PP 34/20 2016, PPAT difficulty in making the deed of sale and purchase of land and/or building rights arise, since in Article 3 paragraph (5) of the Legislation, authorized officers (including PPAT) are prohibited to sign deed (including the sale and purchase deed) before the taxpayer fulfills his obligation to pay the income tax to avoid unrest for the people who will execute the sale and purchase of land rights. The above described phenomenon results in the interest to conduct an investigation to examine the legal consequences emerging in the issuance of the deed of sale and purchase of land rights in the presence of PPAT carried oud in advance to paying off the final Income Tax (PPh).

In relation to the review of the final $\mathrm{PPh}$ on the transfer of land rights, there are a number of studies that have been conducted, started from 2016 [2] until the present day, as elaborated in the following:

A study conducted by Rahman Aulia, entitled "Imposing Income Tax on Purchase of Uncontrolled Land in Padang City, Magister of Notarial Law Faculty of Andalas University," which examines the final income $\operatorname{tax}(\mathrm{PPh})$ payment system and its constraints. In line with this, other study was also conducted by Stefani Yesia Nindy $H$. and Ferry Irawan, entitled: "The Impact of Implementation of Government Regulation Number 34 Year 2016 (Case Study at Primary Tax Office of Kepanjen), State Financial Polytechnic of STAN", which examined the effect of the enactment of Government Regulation No. 34 Year 2016 of the final PPh in the Primary Tax Office of Kepanjen. Furthermore, other related study to the investigation on final income tax was done Bima Satrio Husodo, Sihabudin and Eny Harjati, etitled: "Juridical Review of Income Tax on Sale and Purchase Transaction of Land and/or Buildings, Postgraduate of Faculty of Law Universitas Brawijaya, Malang”, which examines the legal basis in conducting field verification in determining magnitude of the rate of final income tax collection (PPh) on the sale and purchase transactions of land and/or building and income tax collection tariff in Malang. The last other study on final income tax assessment was the one 
carried out by Valensia Nola Putong, Inggriani Elim, and Novi S. Budiarso, entitled: "Analysis of Withholding, Depositing, and Reporting of Final Income Tax on Land and/or Buildings Auction at Manado State Property and Auction Office, Accounting Department, Faculty of Economics and Business Sam University Ratulangi, Manado, which examines the procedures for cutting, depositing and reporting Final Income Tax on land and/or auction at the Manado State Property and Landing Service office.

The difference of the above-mentioned studies from the current research lies in their objectives, that is the present study aims at examining whether or not by implementing the rules regarding the final $\mathrm{PPh}$ payment in the making of the deed of sale and purchase of land rights, the guarantee of legal certainty for society can be created.

In addition, expected implication to be achieved through this study conduction is the determination of legal certainty in making the deed of sale and purchase of land right in the presence of PPAT, so that the society and PPAT attain promising legal protection, and the state receives the income from every sale and purchase transaction of land rights.

\section{METHOD}

This research employs a sociolegal research method. Sociolegal study is a study of law by using the approach of legal science and social sciences [3]. It means to approach the legal problems in accordance with the fact that live in practical life in society. The nature of this research is descriptive, which is a study that provides a systematic description of the object of research [4].

The data used in this study consist of primary data and secondary data. Primary data is the data directly obtained from informants in that have been selected by applying a purposively sampling. The informants were I Ketut Nuridja, $\mathrm{SH}, \mathrm{M} . \mathrm{Kn}$, as a Land Deed Officer in Tabanan Regency; Richard Yerry Puryatma, SH, M.Kn, as a Land Deed Officer in Badung Regency; I Gusti Kardinal Made Mas Wibawa, SH, M.Kn, as a Land Deed Officer in Denpasar City; Anak Agung Gede Oka Aryana, SH, M.Kn, as a Land Deed Officer in Gianyar Regency,; I Nyoman Mudra, SE, MM as the seller of the land; and I Gede Nyoman Chidi Anom, A.Md, as a land buyer.

Furthermore, secondary exploited in this study is obtained from the review of library materials. By viewing from viewpoint of the binding force according Soerjono Soekanto [5], primary and secondary legal materils comprise (a) primary legal material in the form of Civil Code, Law no. 5 Year 1960, Government Regulation (PP) 24 Year 1997, PP 37 Year 1998, PP 34 Year 2016, Regulation of State Minister of Agrarian/Head of National Land Agency Number 3 Year 1997; (b) secondary legal material which provides explanation of primary legal material, in the form of books, articles, journals, papers, research reports relating to the object of research; and (c) tertiary legal materials which provide explanations or clues to primary and secondary legal materials in the form of dictionaries.
Instrument of data collection utilized were two literature review and interview. Library study is useful to collect literature related to the object of research [6]. Interview guidelines are structured or unstructured interviews for researchers who will ask for information from resource persons or the informants [7]. In order to obtain information and input from informant, depth interview was done [8].

\section{RESUlT AND DISCUSSION}

\section{A. Authentic Deed Issuance Procedures}

According to Tan Thong Kie [9], the authentic deeds in its issuance shall comply with three conditions, namely: firstly, shall be made in the presence or by an authorized public official (openbaar ambtenaar); secondly, shall be attended by witnesses; and thirdly, shall be read by the notary and thereafter signed immediately. The word 'in front' indicates that the deed was made at the request of a person, while the word 'made by' due to an event, examination, decision, and so on such as the minutes of the meeting, the news of the drawing event, and so on. The word 'competent public authority' means that the general official to which the deed is made or who makes the deed is a public official authorized to make the deed in that place. The Authority (bevoegd) in this case specifically concerns: (1) his title and the type of deed he made; (2) day and date of the deed; and (3) the place of deed is issued.

Concerning the definition of authentic deed, it is contained in Article 1868 of the Criminal Code, which states:

\section{"An authentic deed is a deed which, in the form prescribed by law, is made by or in the presence of the ruling public officials for it in the place where the deed is issued".}

Authentic deeds or writings are one of the proofs in writing, as specified in Article 1867 of the Criminal Code. Article 1869 of the Criminal Code determines that if a deed which due to no power or incompetence of an officer making, or because of a defect in its form, cannot be treated as an authentic deed, it shall only serve as a deed under the hand. Meanwhile, Article 1870 of the Criminal Code determines that authentic deeds provide a perfect proof for the parties who make it and all their heirs. On the contrary, if a public official declares in the deed, that he has taken action to be done in the authentic deed issuing, but in reality he did not, for example, the deed was actually signed on January 10, 2018 but in a deed written on 25 January 2018, if proven (evidence may be provided by a witness), the general official has made an intellectual forgery (intelectuele vervalsing) [9]. Thus, the deed is not an authentic deed, but merely a deed under the hand (Article 1869 of the Civil Code).

Similarly, that is the central position of authentic deeds in society. Authentic deeds not only provide a strong proof, but provide perfect evidence. Etymologically, the term perfect here means: 1) intact and completely correct (no less or wistful), 2) complete; full, 3) is finished well; well organized, 4) very good; the best [10], thus it can be interpreted that authentic deeds provide complete, complete, orderly, excellent, and complete proof, so there is nothing more to question about it. Authentic deeds provide certainty that what is written in the deed, so events that occurred no less or more. 
The certainty guaranteed in the authentic deed is:

- Definitely about the legal act, meaning: true the legal act that occurs is a legal act that is written in the deed is not another legal act;

- It must be about the time (when the occurrence of legal action / when the act of law is done), meaning: true on the date listed in the deed is when the act of law is done, not another date;

- Definitely about the subject of the law, meaning: true the legal subject contained in the deed is the subject of law that performs legal acts, not other legal subjects;

- It must be about the object. Meaning: true objects or things that become the object of legal action on that date conducted by the subject of the law is the object or thing contained in the deed, not objects or other things;

- Therefore, it must be understood and should always be considered true, that everything that is written and listed in an authentic deed is a real thing as it is not something else. Thus, in order for the deed of sale of rights to land made in the presence of PPAT can be regarded as an authentic deed, it must fulfill the provisions on certainty in issuing authentic deed, which is certain about its legal deeds, definitely about the date, definitely about the subject and definitely about the object.

\section{B. Land Deed Official (PPAT)}

Arrangement of Official Deed Officer Position (PPAT) is in Government Regulation (PP) 37 Year 1998 as amended by PP 24 Year 2016 (PJPPATP). In Article 1 point 1 PJPPATP determines:

"The Land Deed Authority, hereinafter referred to as PPAT, is a public official authorized to make authentic deeds of certain legal acts concerning the right to land or the Property Right of the Housing Unit".

The official of the Deed Authority in making a deed to be authentic in accordance with the intended Article 1868 CIVIL code shall comply with the requirements of the deed as regulated in Article 96 Paragraph (1) of Regulation of the Head of National Land Agency No. 8 of 2012 and Article 101 Paragraph (1) sub-paragraph a of the Regulation of the Minister of Agrarian Affairs/Head of the National Land Agency (PMNA/KBPN) 3 of 1997 as follows: The form of deed used in the deed of making as referred to in Article 95 paragraph (1) and paragraph (2) the way of filling is made in accordance with the Attachment of this Regulation consisting of the Deed of Sale and Sale, it is further determined that the sale and purchase deed must be attended by the seller, the buyer, two witnesses and PPAT (Article 101).

Based on the above illustrations, it can be determined that PPAT is a public official authorized to make an authentic deed regarding the transfer and imposition of land rights. Since the PPAT is a public official, he/she is subject to the provisions of Article 1868 of the Criminal Code and in exercising his/her authority to make a deed which is an authentic deed, he/she is subject to the conditions of making authentic deed.

\section{Land Rights and Sale and Purchase of Land Rights}

Land rights are regulated in Law no. 5 of 1960 on Basic Agrarian Law (UUPA), which is derived from customary law (Article 5). Since agrarian law derives from customary law, all agrarian law institutions also derive from customary law including the concept of selling and purchasing rights to land.

The concept of customary law regarding the sale and purchase of land rights according to Maria S.W. Sumardjono, is [11]:

Cash, meaning the delivery of the land by the seller is done simultaneously with the payment of the price by the buyer

Along with the time of the sale and purchase law, the transfer of land rights occurred. The price paid at the time of the transfer of rights does not have to be paid off or full and this does not diminish the nature of the cash. If there is a difference/residual of the price, then this is regarded as a buyer's debt to the seller who is subject to the law of accounts receivable.

Real, meaning the will or intention spoken must be followed by actions that clearly show the purpose of sale and purchase, for example with the receipt of money by the seller, and the agreement is made in front of the village head.

Frankly, meaning that the legal act must be done in the presence of the village head (customary village head) as a sign that the act does not violate the applicable legal provisions.

Regarding the transfer of land rights regulated in Article 37 paragraph (1) of PP 24 of 1997, determines: The transfer of land rights and property rights of apartment units through sale and purchase that can only be registered if evidenced by deeds made by PPAT authorized according to the provisions of the regulation current regulation. Further Regulation of Minister of Agrarian State (PMNA)/ Head of National Land Agency (KBPN) 3 Year 1997 in Article 95 paragraph (1) letter a determines "Deed of land made by PPAT to be used as registration base of change of land registration data is deed of sale and purchase, which in its issuance must be attended by seller, buyer, and two witnesses, and must be read [12] (Article 101 PMNA/KBPN 3 Year 1997)".

Based on the aforementioned fact it can be observed that a person will earn money which is the income from the sale of his land rights after the deed was signed in the presence of PPAT.

\section{Time of the Final Income Tax Payment}

Regarding the date/time of the Income Tax payment to the State shall be made before the deed is signed (Article 3 paragraph (1)), and the competent authority shall only sign the deed in the showing of photocopy of the Tax Payment Form (Article 3 paragraph (5)). This means that the seller of land rights as a Tax Payer (WP) is obliged to pay the income tax payable to the bank/post perception before the deed is signed by the authorized official [13].

The result of data analysis which was examined using the theory of legal certainty and the theory of authority include the theory of legal certainty that is used is from Sudikno 
Mertokusumo, which states that legal certainty is a protection against the act of yustisiabel arbitrary, which means that one will be able to obtain something expected in certain circumstances [2], while the authority theory used is from Bagir Manan, which states that authority at the same time means rights and obligations. The right contains the freedom to do or not to perform certain acts, or to require other parties to perform or not to perform certain actions, while the obligation contains the obligation to perform or not to take certain actions [14].

Sales and purchase deeds issuance executed before PPAT are authentic deeds that provide the perfect evidence for a buyer and all of its heirs, including others as long as the formal conditions in its manufacture are met. One of the terms and conditions that must be fulfilled by the buyer in the presence of witnesses and PPAT, the seller, and other PPAT at the time of issuance of the land purchase deed is the final income tax must be paid off before the sale and purchase deed signed by PPAT. Between these two provisions there is a distortion of interest between the making of authentic deeds and the state's interest in levying taxes [15].

The state's interest in tax collection results in the provision of $\mathrm{PPh}$ to be paid off before the deed is signed. To comply with these conditions, it is likely that PPAT will take one of the two steps below:

The deed is signed but not dated, after the income tax is payable and then the deed is dated. The following PPh payments and validation of the tax office may take several days, meaning that the date on which the deed is signed is different from the date stated in the deed;

The seller pays the Income Tax first without signing the deed, after the proof of payment of tax is validated by the tax office, the deed is signed and dated.

With regard to the first step, there is clearly a violation in the issuance of an authentic deed which resulted in the deed becoming a deed under the hand and therefore cannot be used to register back the name of the certificate in the Land office, and consequently may harm the purchaser. Conversely, if the second step taken, no one can guarantee the buyer is willing to sign the deed, so potentially harm the seller [16].

A person who sells land rights, certainly hopes to get the money into his income and also used to pay income tax, but if the provision of paying income tax before the deed signed to be enforced, then based on the above two possibilities, the hope becomes unrealized, loss for sellers [17], thus contrary to the theory of legal certainty.

The State in exercising its authority has collected the payment of the Income Tax before the deed is signed, so that the state has earned its right, but the state does not fulfill its obligation to provide legal certainty to the public, thus contrary to the theory of authority.

\section{CONCLUSION}

Based on the result of analysis described above, it can be concluded that the obligation to pay the final income tax (PPh) before the deed is signed as regulated in Article 3 paragraph (5) PP 34 Year 2016 is contradictory to Article 1868 on Civil Code which resulted in absence of legal certainty guarantee for the community so that the objective of PP 24 of 1997, which is contained in the consideration of 'Considering' $b$ is to provide warranty of legal certainty that was realized. This conflict potentially disrupts the balance of the life order of society.

\section{ACKNOWLEDGEMENT}

The author would like to thank all the parties who have helped and contributed in the writing of this article, both those who contribute in the form of funding and critical ideas. Hopefully this paper can be useful theoretically and practically for the addition and development of knowledge, especially in the field of legal science.

\section{REFERENCES}

[1] Roscoe Pound, 1965, Tugas Hukum, ditrjemahkan oleh Muhammad Radjab, Jakarta: Bhratara.

[2] Sudikno Mertokusumo, 2007, Penemuan Hukum (Sebuah Pengantar), Edisi kedua, cetakan kelima, Yogyakarta: Liberty.

[3] Sulistyowati Irianto dan Shidarta, 2009, Metode Penelitian Hukum: Konstelasi dan Refleksi, Jakarta: Yayasan Obor Indonesia.

[4] Bambang Sunggono, 2006, Metodelogi Penelitian Hukum, Jakarta: Raja Grafindo Persada.

[5] Soerjono S, 1986, Pengantar Penelitian Hukum, Jakarta: UI Press.

[6] John W. C., 2009, Research Design: Qualitative, Quantitative and Mixed Methods Approaches, Third Edition, California: Sage Publication.

[7] William L. Neuman, 2006, Social Resiarch Methods: Qualitative and Guantitative Approaches, Sixth Edition, Pearson, USA.

[8] Sabian U, 2010, Dasar-Dasar Sosiologi Hukum: Dilengkapi Proposal Penelitian Hukum (Legal Research), Yogyakarta: Pustaka Pelajar.

[9] Tan Thong Kie, 2007, Studi Notariat dan Serba-Serbi Praktek Notaris, Jakarta: PT. Ichtiar Baru Van Hoeve.

[10] W.J.S. Poerwadarminta, 2006, Kamus Umum Bahasa Indonesia, Edisi Ketiga, Jakarta: BalaiPustaka.

[11] Maria S.W. Sumardjono, 1993, “Aspek Teoritis Peralihan Hak Atas Tanah Menurut UUPA”, Majalah Mimbar Hukum, Fakultas Hukum Universitas Gadjah Mada, No. 18/X/93, Yogyakarta.

[12] PMNA/KBPN No. 3 Tahun 1997 tentang Ketentuan Pelaksanaan PP No. 24 Tahun 1997 tentang Pendaftaran Tanah.

[13] Perkaban No. 8 Tahun 2012 tentang Perubahan Atas PMNA/KBPN No. 3 Tahun 1997 tentang Ketentuan Pelaksanaan PP No. 24 Tahun 1997 tentang Pendaftaran Tanah.

[14] Suko Wiyono, 2004, Pengujian Keabsahan Peraturan Daerah Dalam Rangka Penyelenggaraan Otoda Berdasarkan UU No. 22 Tahun 1999 tentang Pemerintahan Daerah, Malang: Disertasi Progzram Doktor Ilmu Hukum, Fakultas Hukum Universitas Brawijaya.

[15] Results of interview with PPAT I Ketut Nuridja, S.H., M.Kn. on November 30, at his office in Tabanan, also with PPAT Richard Yerry Puryatma, SH, M.Kn, at his office Nakuta street, Kuta, on September 27, and PPAT I Gusti Kardinal Made Mas Wibawa, SH, M. Kn, in his office road Hayamwuruk, denpasar on October 24, 2017.

[16] Results of interview with PPAT Anak Agung Gede Oka Aryana, S.H., M.Kn, via telephone on November 24, 2017.

[17] Results of interview with I Nyoman Mudra, SE, MM, dan I Gede Nyoman Chidi Anom, A.Md, di Desa Berembeng, Kabupaten Tabanan, pada tanggal 20 Januari 2017. 